\title{
Introducing Forensic Accounting In The Intermediate Accounting Class
}

Stephen Tomczyk, Ph.D., CPA, Central Connecticut State University, USA Anne Rich, Ph.D., CPA, CMA, Central Connecticut State University, USA

Keywords: Forensic Accounting, College Accounting, Critical Thinking

\section{INTRODUCTION}<smiles>[SiH3]</smiles>

tudents are introduced to the variety of accounting careers in their financial accounting courses. By the time students select a major, they begin to focus on career options. Students often find themselves fascinated whenever any area of forensic accounting is discussed. This paper provides a brief overview of forensic accounting as well as a case that can be useful in the intermediate accounting class to highlight the role of the forensic accountant.

\section{WHAT IS FORENSIC ACCOUNTING?}

According to one forensic accounting website (www.forensic-accounting-information.com), forensic accounting is the practice of utilizing accounting, auditing, and investigative skills to assist in legal matters. It encompasses two main areas - litigation support, investigation, and dispute resolution. Litigation support represents the factual presentation of economic issues related to existing or pending litigation. In this capacity, the forensic accounting professional quantifies damages sustained by parties involved in legal disputes and can assist in resolving disputes, even before they reach the courtroom. If a dispute reaches the courtroom, the forensic accountant may testify as an expert witness. Parties to a divorce sometimes engage a forensic accounting to determine if there are hidden assets.

\section{THE ACCOUNTING PROFESSION'S RESPONSE}

Forensic accounting has been described as the fastest growing area in accounting. Many firms are now expanding their services to include this area and some firms are exclusively providing only forensic accounting services.

The accounting profession has responded to a growing demand for forensic accounting services in many ways. The American Institute of Certified Public Accountants (AICPA) has expanded their member section that previously focused on valuation services to include forensic service. The Association of Certified Fraud Examiners (ACFE) currently has almost 45,000 members. The organization certifies fraud examiners by issuing the Certified Fraud Examiner (CFE) credential.

There is a journal dedicated to the publication of research related to forensic accounting. The editors of the Journal of Forensic Accounting: Auditing, Fraud, and Risk (JFA) indicates the publication is interested in publishing cases that relate to finding hidden assets in divorce cases for example.

\section{BENEFITS OF INTRODUCING FORENSIC ACCOUNTING CASES IN INTERMEDIATE ACCOUNTING CASES}

Intermediate accounting focuses on learning accounting standards and the preparing of financial statements. The AICPA has indicated that accountants must develop critical thinking skills. Introducing a forensic accounting case early in the intermediate accounting course will help students develop critical thinking skills while creating an 
exciting learning environment. In forensic accounting cases student must develop an ability to think since there is no model in the text to use to solve the fraud.

The case presented in this paper is based on an actual situation and provides a means of discussing accounts receivable and cash flow. The authors were asked to assist in a matter related to a divorce.. This case is associated with accounts receivable and can be introduced early in the intermediate course. Students will be challenged to explain how the owner of the company was able to take cash out of a business. Solving the mystery will help students develop their ability to think. The instructor notes are available from the authors (richann@ccus.edu). The case (EXHIBIT A) will add excitement to the traditional intermediate accounting class!

\section{EXHIBIT A THE CASE OF THE DISAPPEARING CASH}

JWC, Inc. began business in the year 2002. The owner, Jack Carson, was an experienced building contractor with a specialty in installing large windows in commercial buildings. He borrowed money from relatives to purchase the equipment he would need. Jack had hopes of becoming a millionaire within ten years.

When Jack opened his business, the economy was growing and new commercial buildings were going up at a fast rate. He enjoyed a good reputation among builders and his services were in demand. His sales increased. He was able to borrow funds from local banks and through the Small Business Administration (SBA). His employees, all union workers, were paid well. Over the years, Jack bought expensive pieces of equipment that were often idle. He used business funds to pay for personal vacations. Jack lived a very high life style. He owned a boat and two luxury cars, and he took several expensive vacations. During his third year of business, the building industry went into a recession. Jack was unable to keep up the payments on his loans. In January 2008, the economy turned down and large commercial building projects dried up. JWC, Inc.'s sales outlook was bleak. Jack felt his debts were so high that he could no longer continue in business. However, he knew if he simply closed his business, his creditors would aggressively go after him for payment. After speaking with his attorney, Jack decided to seek protection under his state's bankruptcy laws.

Corporations may seek protection under Chapter 7 of the Bankruptcy Code. In Chapter 7 cases, the debtor does not have an absolute right to a discharge. An objection to the debtor's request may be filed by a creditor. After the case is filed in a State District Court, a trustee is appointed. Creditors receive a notice and are directed to file any objection by a specified due date. Filing a complaint starts a lawsuit referred to in bankruptcy as an "adversary proceeding."

While all of his creditors were understandably upset, one particular creditor, Don Ranchet, felt Jack had taken a great deal of cash out of the business during the year prior to declaring bankruptcy. Jack continued to enjoy a life style inconsistent with that of a person who is struggling financially. Jack spent weekends on his large boat, bought his wife expensive jewelry, and ate dinners at up-scale restaurants. Don felt something was not right and wondered if Jack was taking cash from the business to pay his personal expenses while telling the business creditors there was no cash to pay the business debts. Don then read about bankruptcy protection. He learned that the court may deny a Chapter 7 discharge for any reason described in section 727(a) of the Bankruptcy Code. This section identifies several reasons, but two in particular seemed relevant to Mr. Ranchet. The courts may deny the debtor a discharge if it finds that the debtor (1) failed to explain satisfactorily any loss of assets or (2) transferred or concealed property with intent to hinder, delay, or defraud creditors". Mr. Ranchet hired a forensic accountant, Sean Tennant, to determine if any of Jack Carson's actions could be considered fraudulent.

Through Mr. Ranchet's attorney, Sean Tennant gained access to some of the business records of JWC, Inc. Initially, Jack Carson only provided the last two years' financial statements found in Exhibit 1. Mr. Ranchet sent a copy of Sean Tennant's analysis of the financial statements to the bankruptcy trustee, Jessica Bright. 


\section{EXHIBIT 1}

JWC, Inc.

Balance Sheets

At December 31

$\underline{2006} \underline{2007}$

Assets

Cash

Accounts Receivable

Inventory

Equipment, net

Total Assets

\begin{tabular}{rrrrr}
$\$ \quad 9,000$ & & $\$ 10,000$ \\
& 500,000 & & & 250,000 \\
& 150,000 & & & 45,000 \\
& 91,000 & & 130,000 \\
\cline { 1 - 2 } & & & $\$ 435,000$ \\
\hline \hline
\end{tabular}

Liabilities and Equity

Accounts Payable

$\$ 300,000$

\$ 330,000

Long-term Debt

950,000

770,000

Owner's Equity

$(500,000)$

$(665,000)$

Total Liabilities and Equity

$\$ 750,000$

$\$ 435,000$

\section{JWC, Inc.}

\section{Income Statements}

Years Ended December 31

$\underline{2006}$

$\underline{2007}$

Revenues
Less Cost of Goods Sold
Gross Profit
Less Operating Expenses
Net Operating Income
Less Interest Expense
Net Income/(Loss)

$\begin{array}{r}\$ 1,000,000 \\ 700,000 \\ \hline 300,000 \\ 275,000 \\ \hline 25,000 \\ 35,000 \\ \hline \$ \quad(10,000) \\ \hline \hline\end{array}$

$\$ 825,000$

600,000

225,000

300,000

$(75,000)$

45,000

$\$(120,000)$

After reviewing the financial statements, Sean Tennant drew up a list of additional documents he wanted to review. These included the details of the accounts receivable as well as the details of the long-term debt. JWC, Inc. then provided the following information (Exhibits 2 and 3): 


\section{EXHIBIT 2}

JWC, Inc. Accounts Receivable

Customer

D.F. Colbert

F. B. Wright

L.D.W., Inc.

Big Builder, Inc.

Stafford Builders

Amity Construction

Total
At December 31
$\underline{2006} \quad \underline{2007}$

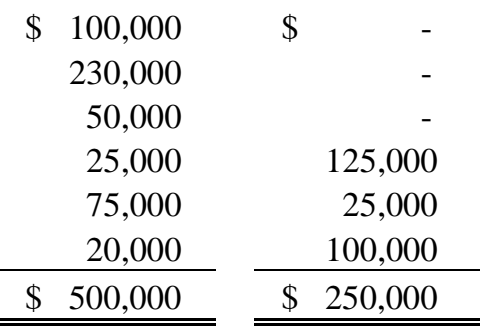

\section{EXHIBIT 3}

JWC, Inc. Long-term Debt
Creditor

Bank of Chicago

First National Bank Loan

Small Business Administration Loan

Loan Payable D. Ranchet

Officer Loan

Total

\begin{tabular}{|c|c|c|c|}
\hline \multicolumn{2}{|c|}{2006} & \multicolumn{2}{|c|}{$\underline{2007}$} \\
\hline$\$$ & 75,000 & $\$$ & 100,000 \\
\hline & 190,000 & & 200,000 \\
\hline & 185,000 & & 185,000 \\
\hline & 350,000 & & 350,000 \\
\hline & 150,000 & & $(65,000)$ \\
\hline$\$$ & 950,000 & $\$$ & 770,000 \\
\hline
\end{tabular}

Mr. Tennant reviewed the accounts receivable and long-term debt records. He then issued the following report (Exhibit 4):

\section{EXHIBIT 4: LETTER FROM FORENSIC ACCOUNTANT, SEAN TENNANT}

TO:

Don Ranchet

FROM: Sean Tennant

DATE: $\quad$ July 18,2008

RE: $\quad$ Examination of financial documents of JWC, Inc. 
On July 8 and July 10, 2008, I examined nine boxes of documents pertaining to JWC, Inc., at the Olsen Law Offices, 148 Main Street, Chicago, IL Most of the documents were of a financial nature, though some were technical and pertained to the operations of the window installation business. The financial documents were comprised of payroll registers, payroll account bank statements and canceled checks, payroll information for the Local Carpenters Union, operating account check registers, operating account bank statements and canceled checks, and bank deposit information. There were also records pertaining to business loans and repayments, and lines of credit. The purpose of my examination was to determine how much cash was withdrawn by Mr. Jack Carson during 2006 and 2007 from JWC, Inc., prior to the company's filing for bankruptcy. My observations and findings follow.

1. During 2007, five checks were drawn to Jack Carson, president of JWC, Inc. These checks totaled $\$ 10,000$. A list of the checks appears in the attached table. The explanation for the checks is Officer Loan Payment.

2. Gross wages and salaries paid to Jack Carson during 2006 and 2007 are as follows:

\begin{tabular}{lr}
2006 salary & $\$ 70,000$ \\
2007 salary & $\underline{72,000}$ \\
Total & $\underline{\$ 142,000}$ \\
\hline
\end{tabular}

Payroll taxes on these salaries were paid by JWC, Inc.

3. Many of the requested documents were not produced by the defendant, Jack Carson. For example, Mr. Ranchet had requested that "Financial statements for the past five years prepared by an accountant or any other person with respect to you or any business in which you had an interest or were an employee" be provided. I did not find copies of these statements in the Olsen Law Offices. Moreover, Mr. Ranchet requested that "All ledgers, books, accounts, cash receipt journals, accounts receivable, accounts payable, and all other accounts kept or maintained by you (or under your supervision and direction) in connection with any business or businesses during the past three years to the present date, including rents received from any tenants of yours for all property for which you have any interest" be provided. I did not find copies of these items in the boxes stored in the Olsen Law Offices.

4. Repayments of loans are one way that Mr. Carson might have withdrawn funds from his company. Borrowing from the company is another means of withdrawing corporate cash. It is notable that the Officer Loan account went from a balance of $\$ 150,000$ on December 31,2006 , to a balance of $(\$ 65,000)$ on December 31, 2007 . The difference in the balances is a reduction of $\$ 215,000$. Ordinarily, a reduction in a loan payable account is accompanied by a simultaneous decrease in cash. However, the checks mentioned in item 1 only record of such a significant decrease in cash in the documents that I examined. If Mr. Carson's accountant were to provide the records requested by Mr. Ranchet, I might be able to shed some light on this matter. I would need to see an analysis of the Officer Loan account in order to provide a more complete explanation of the reduction.

5. Some further explanation of the change in the Officer Loan account is warranted at this point. The reduction in the balance from $\$ 150,000$ on December 31,2006 , to

$-\$ 65,000$ on December 31,2007 , may actually be viewed as two transactions. The reduction from $\$ 150,000$ to zero should be viewed as the repayment in full of a loan that Mr. Carson made to JWC, Inc. The reduction from zero to $\$ 65,0005$ should be viewed as a loan made by JWC, Inc., to Mr. Carson. Both of these transactions would ordinarily require the payment of cash by a company. As I mentioned above, however, I could find no evidence of such payments in the documents that I examined.

6. Because a major source of cash for a business is the collection of accounts receivable, it would be useful to have an analysis of receivables for the past three years. Were any receivables written off and subsequently collected? If so, were the proceeds deposited in the operating account of the company?

When the documents that were requested by Mr. Ranchet (discussed above) are produced by Mr. Carson, I will be able to continue my examination and render an opinion regarding how much additional cash was withdrawn by Mr. Clark JWC, Inc. In the meantime, I suggest that you obtain credit reports for Mr. Carson and for JWC, Inc. These reports should list all bank accounts under the control of Mr. Carson and J.W. C, Inc. 
After receiving Sean Tennant's report, the trustee, Jessica Bright, ordered Jack Carson to provide copies of his personal bank statements. Of particular interest were transactions associated with a personal line of credit. Exhibit 5 provides a summary of those transactions.

\begin{tabular}{|c|c|c|c|}
\hline \multirow[b]{2}{*}{ Date } & \multicolumn{3}{|c|}{$\begin{array}{c}\text { EXHIBIT } 5 \\
\text { Jack Carson's Personal Line of Credit }- \text { Principal Balance }\end{array}$} \\
\hline & $\underline{\text { Transaction }}$ & $\underline{\text { Amount }}$ & Balance \\
\hline Jan. 1, 2007 & Loan balance & & $\begin{array}{l}\$ \\
26,730\end{array}$ \\
\hline Sept. 3, 2007 & Payment & $\begin{array}{l}\$ \\
(25,000)\end{array}$ & 1,730 \\
\hline Sept. 3, 2007 & Withdrawal & 25,000 & 26,730 \\
\hline Oct. 15, 2007 & Payment & $(5,000)$ & 21,730 \\
\hline Oct. 16, 2007 & Payment & $(20,000)$ & 1,730 \\
\hline Oct. 16, 2007 & Withdrawal & 25,000 & 26,730 \\
\hline Nov. 13, 2007 & Payment & $(10,000)$ & 16,730 \\
\hline Nov. 13, 2007 & Withdrawal & 10,000 & 26,730 \\
\hline Nov. 28, 2007 & Payment & $(20,000)$ & 6,730 \\
\hline Nov. 28, 2007 & Withdrawal & 20,000 & 26,730 \\
\hline Dec. 5, 2007 & Payment & $(18,000)$ & 8,730 \\
\hline Dec. 6, 2007 & Payment & $(8,000)$ & 730 \\
\hline Dec. 6, 2007 & Withdrawal & 26,000 & 26,730 \\
\hline Dec. 17, 2007 & Payment & $(15,000)$ & 11,730 \\
\hline Dec. 17, 2007 & Withdrawal & 15,000 & 26,730 \\
\hline Dec. 23, 2007 & Payment & $(20,000)$ & 6,730 \\
\hline Dec. 23, 2007 & Withdrawal & 20,000 & 26,730 \\
\hline Dec. 29, 2007 & Payment & $(10,000)$ & 16,730 \\
\hline Dec. 29, 2007 & Withdrawal & 10,000 & 26,730 \\
\hline
\end{tabular}


Required:

1. After reading Sean Tennant's report, what questions do you have concerning (1) accounts receivable and (2) the officer loan account?

2. Analyze the change in owner's equity. What questions do you have concerning the owner's equity account?

3. Can you find evidence of cash disappearing?

4. Do you believe Don Ranchet and the other creditors have been defrauded by Jack Carson?

\section{AUTHOR INFORMATION}

Anne Rich is a professor of accounting at Central Connecticut State University and at Kaplan University. She holds a Ph.D.in accounting from the University of Massachusetts. She is a Certified Public Accountant and a Certified Management Accountant. Dr. Rich research focuses on developing students' critical thinking skills

Stephen Tomczyk is Associate Professor of Accounting at Central Connecticut State University. He received his D.B.A. from the University of Kentucky and is a Certified Management Accountant. His teaching and research interests include international accounting and corporate financial reporting and analysis

\section{NOTES}




\section{NOTES}

